\title{
FRUIT CONSUMPTION AND SEED DISPERSAL OF Dimorphandra mollis BENTH. (LEGUMINOSAE) BY THE LOWLAND TAPIR IN THE CERRADO OF CENTRAL BRAZIL
}

\author{
BIZERRIL, M. X. A., ${ }^{1}$ RODRIGUES, F. H. G. ${ }^{2,3}$ and HASS, A. ${ }^{3}$ \\ ${ }^{1}$ Faculdade de Ciências da Saúde, Centro Universitário de Brasília, UniCEUB, \\ SEPN 707/907, CEP 70790-075, Brasília, DF, Brazil \\ ${ }^{2}$ Associação para Conservação dos Carnívoros Neotropicais, Associação Pró-carnívoros, SQN 412, \\ Bloco K, ap. 305, CEP 70867-110, Brasília, DF, Brazil \\ ${ }^{3}$ Departamento de Zoologia, Universidade de Brasília, CEP 70910-900, Brasília, DF, Brazil \\ Correspondence to: Marcelo X. A. Bizerril, Faculdade de Ciências da Saúde, Centro Universitário de Brasília, \\ UniCEUB, SEPN 707/907, CEP 70790-075, Brasília DF, Brazil, e-mail: marcelo051529@uniceub.br \\ Received September 22, 2003 - Accepted November 27, 2003 - Distributed August 31, 2005
}

(With 2 figure)

\begin{abstract}
Fruit phenology observations and consumption of Dimorphandra mollis (Leguminosae) were analyzed during seven months in an area of cerrado stricto sensu. We analysed 81 fecal samples collected at six different places of lowland tapirs (Tapirus terrestris) in central Brazilian cerrado. In addition, from the feces of five tapirs at the Brasília Zoo to which fruit had been offered, seeds were collected and used in germination tests. The results suggest that the tapir is an important fruit consumer and a potential seed disperser of $D$. mollis. In the field, however, fruit consumption was found to be very low, probably because of both fruit palatability and the low density of frugivores, especially tapirs. The possibility that the original dispersal agents of D. mollis seeds belonged to the South American Pleistocene megafauna is discussed.
\end{abstract}

Key words: lowland tapir, cerrado, Dimorphandra, fruit palatability, pleistocene herbivores.

\section{RESUMO}

Consumo dos frutos e dispersão de sementes de Dimorphandra mollis Benth. (Leguminosae) pela anta no cerrado do Brasil Central

A frutificação de Dimorphandra mollis e o destino dos frutos foram analisados por 7 meses em uma área de cerrado stricto sensu no Distrito Federal. Analisamos 81 amostras de fezes de anta (Tapirus terrestris) coletadas em 6 áreas de cerrado no Brasil Central e oferecemos frutos a 5 antas no zoológico de Brasília. As fezes foram coletadas e as sementes usadas em testes de germinação. A anta é importante consumidor dos frutos e potencial dispersor das sementes. Contudo, o consumo de frutos no campo foi reduzido provavelmente em razão da palatabilidade dos frutos e da baixa densidade de frugívoros, especialmente antas. Discutimos a possibilidade de os dispersores originais pertencerem à megafauna extinta de mamíferos da América do Sul.

Palavras-chave: anta, cerrado, Dimorphandra, palatabilidade de frutos, herbívoros pleistocênicos. 


\section{INTRODUCTION}

The role of large frugivores as seed dispersors is still largely unknown in Brazil. In the Amazon Forest, ungulates (peccaries, tapirs, and deers), are important fruit consumers and possibly effective seed dispersers (Bodmer, 1991; Fragoso, 1997). In cerrado vegetation, little is known about interactions between plants and large frugivorous mammals; however, this is not so for the relationship between the lowland tapir (Tapirus terrestris) and the palm tree Buriti (Mauritia flexuosa) (Prada, 1994) as indicated by studies on the canid diet (such as those of Dietz, 1984; Motta-Júnior et al., 1994; Dalponte, 1997; Juarez \& Marinho-Filho, 2002; Rodrigues, 2002, and others).

The Leguminosae family, which is well represented in the tropics, is one of the richest families in the cerrado biome, with more than 750 species (Mendonça et al., 1998). Plants of this family exhibit varied habits: from herbs and bushes, to creepers and trees. Most of the species occur in savanna formations within the cerrado and produce dry fruits. In many cases, the seeds are winddispersed. However, some species present zoochoric fruits, which are fleshy and odoriferous.

Dimorphandra mollis Benth. (Leguminosae, Mimosoidae) is a typical cerrado tree. It attains up to 10 meters in height and its fruits, which grow in bunches (Fig. 1), and ripen in central Brazil during the dry season, especially from June to August. The fruit is a green, indehiscent legume with a farinaceous mesocarp that becomes more rigid and changes coloration to dark brown as it ripens (Heringer \& Ferreira, 1973; Almeida et al., 1998). It also produces a sweet caramel-like scent. $D$. mollis fruits are an important resource for local inhabitants who sell it by the ton to the pharmaceutical industry (Gomes \& Gomes, 2000).

The aim of this study is to describe not only this fruit's phenology but also the relationship of Dimorphandra mollis with the lowland tapir (Tapirus terrestris).

\section{MATERIAL AND METHODS}

The study was conducted at both the Águas Emendadas Ecological Station (ESEC-AE), located $40 \mathrm{~km}$ from Brasília in the northeastern portion of the Federal District (15'32'S and 47 $33^{\prime}$ W), and the Brasília Zoo. This 10,500-hectare reserve contains representative samples of the main cerrado-biome vegetation types, which are predominantly of cerrado stricto sensu (semideciduous, xeromorphic tree/ shrub woodland with an open canopy and a ground cover of forbs and grasses) and vereda (a marsh grassland habitat associated with forest boundaries and the occurrence of the palm tree Buriti). The dry season occurs between May and September, with monthly mean precipitation of $24.3 \mathrm{~mm}$, and the rainy season between October and March, with monthly mean precipitation of $212.4 \mathrm{~mm}$. Dimorphandra mollis is a common tree in ESEC$\mathrm{AE}$, with density in the study area of 30 individuals per hectare (Silva Júnior \& Felfili, 1996).

The study was conducted in a 1 ha area of cerrado stricto sensu, between May and December 1998. In May, the beginning of the fruiting season, all fruits produced by eleven individuals of $D$. mollis were counted. Thirty fruits were collected for measuring length, width, and weight of fruits and seeds, as well as for registering seed production. For the phenological study, 207 fruits collected from 11 plants were labelled. The fruits were marked unripe at the beginning of the fruiting season. Fruits were observed weekly during seven months. Ripening, fruit fall under the parent plant, and occurrence or not of consumption by animals were recorded.

We analyzed 81 tapir fecal samples in addition to searching for and counting the $D$. mollis seeds. The fecal samples were collected at 6 different cerrado areas in central Brazil: Emas National Park (Mineiros, Goiás State), Serra da Mesa (Minaçu, Goiás State), Brasília National Park (Federal District), São Miguel Farm (Unaí, Minas Gerais State), Jatobá Farm (Correntina, Bahia State), and Nova Xavantina (Mato Grosso State).

Furthermore, a total of 180 fruits placed at a distance of $20 \mathrm{~m}$ from the closest individual were offered twice within fifteen days to 5 tapirs at the Brasília Zoo. After four days tapir fecal samples were collected and seeds used in germination tests.

The germination experiments were conducted using three groups of seeds obtained from three sources: (1) ripe fruits; (2) samples of tapir feces collected in São Miguel Farm (in Unaí District, Minas Gerais State); and (3) feces from tapirs in captivity. The seeds were maintained in acrylic boxes with vermiculite substrate at room temperature (approx. $25^{\circ} \mathrm{C}$ ) under natural light. Each lot of seeds was observed for 240 days. 


\section{RESULTS}

\section{Fruit production and phenology}

Each plant produced $121.5 \pm 86.1$ fruits (range of $15-272 ; \mathrm{n}=11$ ). We estimated that each plant produces about 1,900 seeds in each reproductive season, based on an average of 16 seeds per fruit (Table 1).

The ripening of $D$. mollis fruits lasted for about one week after the process started. When ripe, the fruits fell to the ground where they accumulated beneath the tree. By the eighth week, most of the fruits had matured and fallen, and by week 17 all marked fruits were under the plants (Fig. 2). These fruits remained under the tree for more eight weeks, when their skins began to present sun-drying signs, following which the skin broke and the fruits opened, thus exposing the seeds. Since this period coincided with the beginning of the rainy season, several seeds were fungus-damaged. By week 31 all marked fruits had dried up and released the seeds. During the whole study period, only five fruits disappeared (by week 17). No other evidence of seed removal or fruit consumption was found.

\section{Tapir fruit consumption and seed germination}

Of the 81 analyzed tapir fecal samples collected in the field, 33 contained seeds of $D$. mollis (Table 2). We found $50.8 \pm 98.5$ seeds per sample (range of 1-454), of which $94 \%$ were intact after going through the tapir's gut.

After the fruits were presented to the captive tapirs, they sniffed the air, got up, approached the fruits, and consumed all them. Large chunks of fruit were torn during mastication and ingested. After four days, intact seeds were collected from the feces.

The seed-germination rates were low, not exceeding 15\% (Table 3). Seeds removed from ripe fruits, from feces collected in the field, and from those in captivity all had similar germination rates $\left(\chi^{2}=1.22 ; \mathrm{df}=2 ; \mathrm{p}>0.05\right)$.

TABLE 1

Characteristics of Dimorphandra mollis fruits and seeds at ESEC-AE, Brazil.

\begin{tabular}{|c|c|c|}
\hline Characteristics & Average (SD) & N \\
\hline Fruit length $(\mathrm{cm})$ & $14.1(1.5)$ & 30 \\
\hline Fruit width (cm) & $3.3(0.3)$ & 30 \\
\hline Fruit fresh weight (g) & $26.2(4.4)$ & 11 \\
\hline Seeds per fruit & $16(1)$ & 20 \\
\hline Seed length (cm) & $1.3(0.1)$ & 20 \\
\hline Seed width (cm) & $0.6(0.1)$ & 20 \\
\hline Seed weight (mg) & $287(27)$ & 11 \\
\hline Fruits per plant & $121(86)$ & \\
\hline
\end{tabular}

TABLE 2

Fecal samples of Tapirus terrestris and occurrence of Dimorphandra mollis seeds.

\begin{tabular}{|l|c|c|c|}
\hline \multicolumn{1}{|c|}{ Sites (State) } & $\begin{array}{c}\text { Number of fecal } \\
\text { samples }\end{array}$ & $\begin{array}{c}\text { Samples with } \\
\text { D. mollis seeds }\end{array}$ & $\begin{array}{c}\text { Frequency } \\
(\%)\end{array}$ \\
\hline Brasília National Park (DF) & 6 & 3 & 50.0 \\
\hline Nova Xavantina (MT) & 10 & 5 & 50.0 \\
\hline Emas National Park (GO) & 20 & 2 & 10.0 \\
\hline Serra da Mesa (GO) & 26 & 12 & 46.2 \\
\hline São Miguel Farm (MG) & 11 & 9 & 81.8 \\
\hline Jatobá Farm (BA) & 8 & 2 & 25.0 \\
\hline Total & 81 & 33 & 40.7 \\
\hline
\end{tabular}




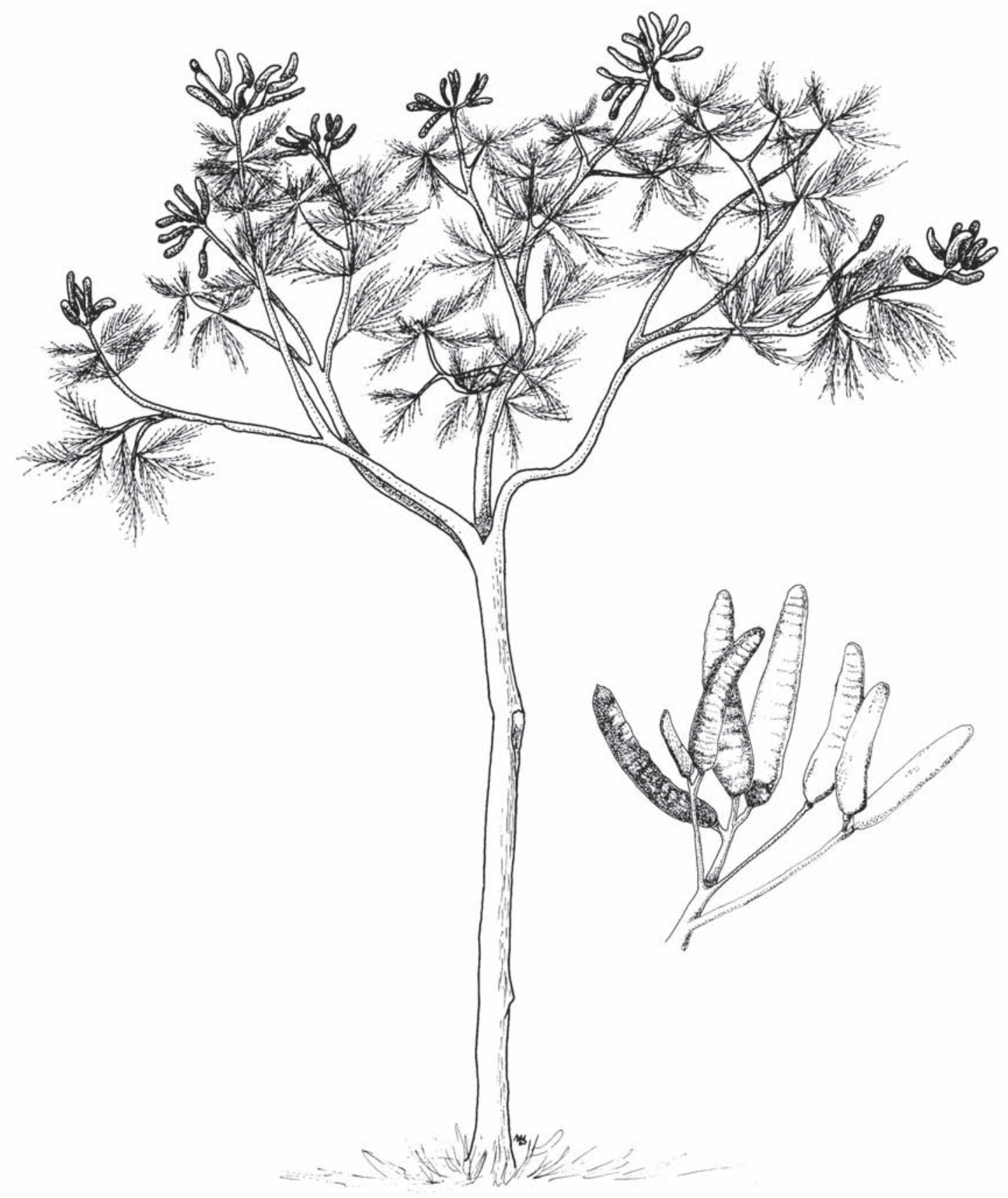

Fig. 1 - Reproductive individual of Dimorphandra mollis in detail, ripe (dark) and unripe (clear) fruits. 


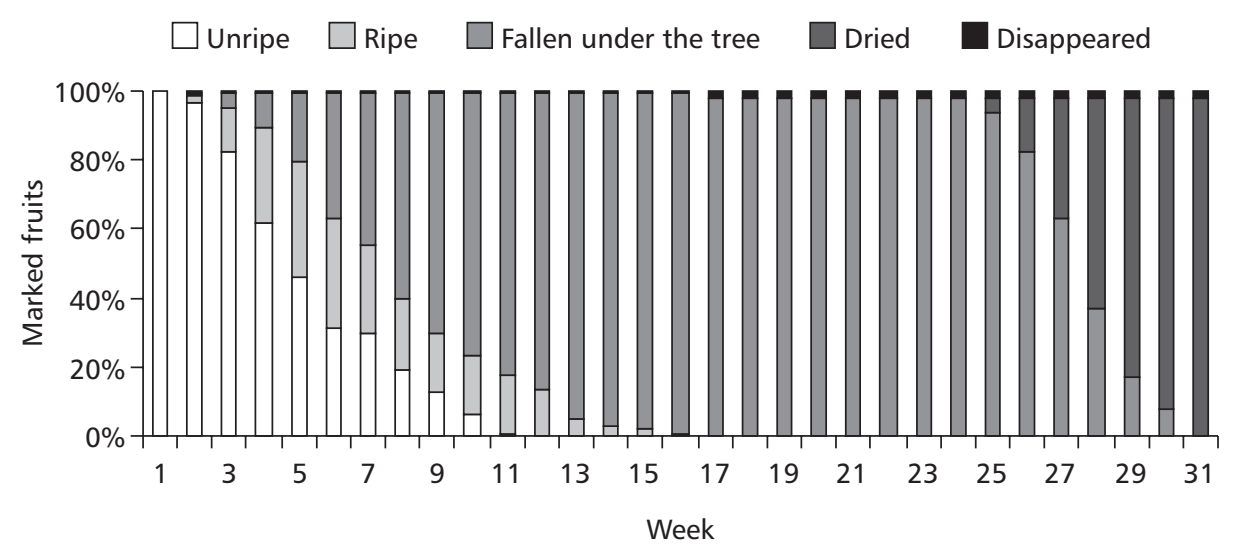

Fig. 2 - Ripening and destination of 207 marked fruits of Dimorphandra mollis at ESEC-AE, Brazil..

TABLE 3

Germination of Dimorphandra mollis seeds from three sources.

\begin{tabular}{|c|c|}
\hline Source & Percentage of germinated seeds $(\mathbf{N})$ \\
\hline Ripe fruit & $12.9(124)$ \\
\hline Tapir fecal samples (nature) & $14.3(70)$ \\
\hline Tapir fecal samples (captivity) & $9.6(177)$ \\
\hline
\end{tabular}

\section{DISCUSSION}

The low consumption of $D$. mollis fruits in the study area was an unexpected finding since they are abundant (about $95 \mathrm{~kg} / \mathrm{ha}$, with a density of 30 individuals per hectare) and ripen in the dry season when little food is available for herbivores (Rodrigues, 1996; Oliveira, 1998). Furthermore, the ripe fruit is aromatic and attractive to frugivores, especially mammals (Van der Pijl, 1982). However, it is also highly toxic (Sorensen, 1983; Bodmer, 1991; Bizerril \& Gastal, 1997) in cattle and, depending on the quantity ingested, can cause serious intestinal disturbances, miscarriage, and even death (Almeida et al., 1998). It is also known as a plentiful source of rutin, a substance that causes uterine contractions and increases bloodvessel permeability and resistance (Ferreira, 1971; Heringer \& Ferreira, 1973; Almeida et al., 1998).

Another finding of the present study was that, in contrast with the low consumption recorded in ESEC-AE, fruits of $D$. mollis are consumed with greater frequency in other places. In the cerrado biome, tapirs seem to be one of the main consumers of these fruits, and their acceptance by tapirs in captivity supports the hypothesis that this species is also an important consumer in Brazil, where the genus itself is popularly known as tapir-fruit or fava d'anta (Gomes \& Gomes, 2000). In addition, deer consume these fruits, but with lower frequency (we found only two intact seeds of D. mollis in fecal samples of Mazama sp.); it is also eaten by rodents, such as Oryzomys scotti (F. H. G. Rodrigues, personal observation), and probably, by peccaries as well.

Tapirs are considered rare in the reserve (Marinho-Filho et al., 1998), and reduced wild-animal densities may influence environmental dynamics of the environment, especially because of the relationships between frugivores and plants (Howe, 1984; Redford, 1992). The consequent dispersal reduction could be affecting the reproductive success of D. mollis in ESEC-AE, since $97.6 \%$ of the marked fruits stayed under the parent-tree until it rots. 
Another possible explanation of the low fruit consumption is that the original dispersers of $D$. mollis belonged to extinct South American megafauna. Janzen \& Martin (1982) suggested that most interactions between fruits and frugivores were established prior to the last 10,000 years of Pleistocene when, in addition to tapirs, deer, and peccaries, ground sloths, gomphotheres (mastodonlike proboscidians), glyptodonts, and other extinct large herbivores were also common. With the abrupt extinction of pleistocene megafauna, some fruit species lost their main dispersers; the current fauna consuming these fruits can be conceived of functioning as seed predators or ineffective dispersers.

A list of 15 Brazilian plant species whose seeds were probably dispersed by the extinct megafauna was presented by Guimarães Jr. \& Galetti (2001), although the theory upon which the list is based is not accepted by some authors (see Howe, 1985). Dimorphandra mollis was not included in this list, but the fruit fits most of the proposed characteristics found in the so-called megafauna dispersal syndrome proposed by Janzen \& Martin (1982): (1) it is large and indehiscent; (2) it drops from the tree shortly after ripening; (3) it does not attract arboreal or winged dispersal agents; (4) most of the fruits rot under the parent tree; (5) they are avidly consumed by introduced large mammals like cattle and horses; and (6) tapirs, peccaries, and rodents act as predators or as the only seed dispersors.

Our results showed that $D$. mollis seeds are frequently found in tapir feces, but also that most of the fruit crop rots under the trees. This fact is apparently related to the low density of frugivores, especially tapirs, that are able to consume these fruits and disperse the seeds. In some areas of the cerrado biome in which $D$. mollis fruits are an important resource for the local population, low consumption by fauna allows a high proportion of the fruits to be exploited sustainably. In conclusion, more research on $D$. mollis fruit production and consumption in other cerrado sites is essential to shed light on the relationships of this plant with frugivores and to develop plans for its sustainable use.

Acknowledgements - We thank ESEC-AE for granting us access to the grounds and also for field assistance, with which Raquel Grando was also involved. The Fundação Polo Ecológico Brasília Zoo, represented mainly by Keila Juarez and Marcelo
Reis, kindly permitted work at the Brasília Zoo. José Bizerril and Rodolfo A. Salm participated in producing the English version of the text. Marcos A. S. Silva made the drawings of Dimorphandra mollis.

\section{REFERENCES}

ALMEIDA, S. P., PROENÇA, C. E., SANO, S. M. \& RIBEIRO, J. F., 1998, Cerrado: espécies vegetais úteis. EmbrapaCPAC, Planaltina, DF, pp. 150-155.

BIZERRIL, M. X. A. \& GASTAL, M. L. A., 1997, Fruit phenology and mammal frugivory in Renealmia alpinia (Zingiberaceae) in a gallery forest of central Brazil. Rev. Brasil. Biol., 57(2): 305-309.

BODMER, R. E., 1991, Strategies of seed dispersal and seed predation in Amazonian Ungulates. Biotropica, 23(3): 255261.

DALPONTE, J. C., 1997, Diet of the hoary fox, Lycalopex vetulus, in Mato Grosso, Central Brazil. Mammalia, 61(4): 537-546.

DIETZ, J. M., 1984, Ecology and social organization of the maned wolf. Smithsonian Contrib. Zool., 392: 1-51.

FERREIRA, M. B., 1971, As plantas tóxicas no Distrito Federal. Cerrado, 3(14): 26-30.

FRAGOSO, J. M. V., 1997, Tapir-generated seed shadows: scaledependent patchiness in the Amazon rain forest. J. Ecology, 85: 519-529.

GOMES, L. J. \& GOMES, M. A. O., 2000, Extrativismo e biodiversidade: o caso da fava-d'anta. Ciência Hoje, 27(161): 66-69.

GUIMARÃES JR., P. R. \& GALETTI, M., 2001, Frutos dispersos por mamíferos extintos. Ciência Hoje, 29(173): 83-85.

HERINGER, E. P. \& FERREIRA, M. B., 1973, Árvores úteis da região geoeconômica do DF: Faveiro do Campo. O gênero Dimorphandra Schott. Cerrado, 5(20): 26-31.

HOWE, H. F., 1984, Implications of seed dispersal by animals for tropical reserve management.Biological Conservation, 30: 261-281.

HOWE, H. F., 1985, Gomphothere fruits: a critique. The American Naturalist, 125(6): 853-865.

JANZEN, D. H. \& MARTIN, P. S., 1982, Neotropical anachronisms: the fruits the Gomphotheres ate. Science, 215(1): 19-27.

JUAREZ, K. M. \& MARINHO-FILHO, J. S., 2002, Diet, habitat use, and home ranges of sympatric canids in Central Brazil. J. Mamm., 83(4): 925-933.

MARINHO-FILHO, J., RODRIGUES, F. H. G., GUIMARÃES, M. M. \& REIS, M. L., 1998, Os mamíferos da Estação Ecológica de Águas Emendadas, Planaltina, DF, pp. 3463. In: J. Marinho-Filho, F. Rodrigues \& M. Guimarães (eds.), Vertebrados da Estação Ecológica de Águas Emendadas: história natural e ecologia em um fragmento de cerrado do Brasil Central. SEMATEC-IEMA, Governo do Distrito Federal, Brasília, DF. 
MENDONÇA, R. C., FELFILI, J. M., WALTER, B. M. T., SILVA JÚNIOR, M. C., REZENDE, A. V., FILGUEIRAS, T. S. \& NOGUEIRA, P. E., 1998, Flora vascular do Cerrado, pp. 89-168. In: S. M. Sano \& S. P. Almeida (eds.), Cerrado: ambiente e flora. Embrapa-CPAC, Planaltina, DF.

MOTTA-JÚNIOR, J. C., LOMBARDI, J. A. \& TALAMONI, S. A., 1994, Notes on crab-eating fox (Dusicyon thous) seed dispersal and food habits in southeastern Brazil. Mammalia, 58(1): 156-159.

OLIVEIRA, P. E., 1998, Fenologia e biologia reprodutiva das espécies de Cerrado, pp. 169-192. In: S. M. Sano \& S. P. Almeida (eds.), Cerrado: ambiente e flora. Embrapa, Brasília, DF.

PRADA, M., 1994, Guilda de frugívoros associada com o buriti (Mauritia flexuosa: Palmae) numa vereda no Brasil Central. Tese de Mestrado, Departamento de Ecologia, Universidade de Brasília, Brasília, DF.

REDFORD, K. H., 1992, The empty forest. BioScience, 42(6): 412-422.
RODRIGUES, F. H. G., 1996, Influência do fogo e da seca na disponibilidade de alimento para herbívoros do cerrado, pp. 76-83. In: H. S. Miranda, C. H. Saito \& B. F. S. Dias (eds.), Impactos de queimadas em areas de cerrado e restinga. Universidade de Brasília, Brasília, DF.

RODRIGUES, F. H. G., 2002, Biologia e conservação do loboguará na Estação Ecológica de Águas Emendadas, DF. Tese de Doutorado. Universidade Estadual de Campinas UNICAMP, SP. ix $+96 \mathrm{p}$.

SILVA JÚNIOR, M. C. \& FELFILI, J. M., 1996, A vegetação da Estação Ecológica de Águas Emendadas. Secretaria de Meio Ambiente, Ciência e Tecnologia do Distrito Federal/ SEMATEC-GDF, Brasília, DF, 43p.

SORENSEN, A. E., 1983, Taste aversion and frugivore preference. Oecologia, 56: 117-120.

VAN DER PIJL, L., 1982, Principles of dispersal in higher plants, $3^{\text {rd }}$ ed. Springer-Verlag, Berlin, 214p. 